Esta revista forma parte del acervo de la Biblioteca Jurídica Virtual del Instituto de Investigaciones Jurídicas de la UNAM

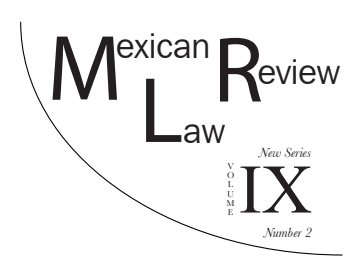

\title{
UNDERSTANDING CONSTITUTIONAL AMENDMENTS IN MEXICO: PERPETUUM MOBILE CONSTITUTION
}

\author{
Mauro Arturo RIVERA LEÓN*
}

ABSTRACT. In spite of being formally rigid, the Mexican Constitution is frequently amended. In this article, I analyze the constitutional amendment procedure in order to understand the causes, consequences and potential solutions of the accelerated rhythm of constitutional amendments in Mexico.

Key wORDs: Constitutional amendment, rigid constitutions, flexible constitutions.

Resumen. A pesar de ser formalmente rígida, la Constitución mexicana ha sido reformada con gran frecuencia. En el presente artículo se analiza el procedimiento de reforma constitucional para entender las causas, consecuencias y potenciales soluciones al acelerado ritmo de reformas constitucionales en México.

Palabras Clave: Reforma constitucional, Constituciones rígidas, Constituciones flexibles.

TABLE OF CONTENTS

I. BRYCE REVISITED: FLEXIBLE AND RIGID GONSTITUTIONS .......................... 4

1. ACAdEMiC GLASSIFICATION ......................................................... 4

2. FormalLy RIGID, MATERIALLY FLEXIBLE ….................................... 6

3. Consequences AND PROBlems OF HiPER-REFormism ........................ 8

II. The AMENDMENT PROCEDURE................................................................ 10

* PhD in Law (Universidad Complutense de Madrid). Currently working at the Mexican Supreme Court. Lecturer on Constitutional Law at Universidad Iberoamericana. E-mail: arturo.riverale@gmail.com Twitter: @MauroArturo.Para mi maestro Diego Valadés con admiración y afecto. I am grateful to Barbara Stepien, Yessica Esquivel and Armando Salas for their insightful comments on earlier drafts of this manuscript. The usual disclaimer applies. 
Esta revista forma parte del acervo de la Biblioteca Jurídica Virtual del Instituto de Investigaciones Jurídicas de la UNAM

1. AN HISTORICAL OVERVIEW.

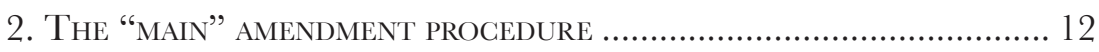

3. TERritorial constitutional AMENDMENT PROCEDURES.................. 13

A. The fleXible terRitorial Procedure ..................................... 14

B. Converting territories into States: the Repealed CONVERsion

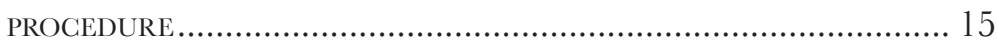

C. The Ultra-RIGID terRitorial DIVISION PROCEDURE..................... 16

D. BRYCE AND THE CAPACITY OF CONSTITUTIONS FOR TERRITORIAL EXPANSION

III. Gauses of THE HYPER-AMENDMENT ................................................ 18

1. The HegEmony of A POLITICAL PARTy ............................................. 20

2. A political concePtion of the CONSTITUtion ............................. 22

3. The Regulatory nature of Constitutional Provisions ............... 23

4. Centralization and federalism .................................................. 25

5. Is ARTICLE 135 AN "EASY PROCEDURE"? ........................................... 26

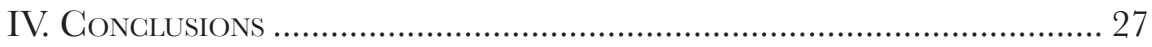

\section{BRYCE REVISITED: FLEXIBLE AND RIGID CONSTITUTIONS}

\section{Academic classification}

James Bryce, a constitutional scholar, is better known for his famous characterizations of constitutions as rigid or flexible. In his prominent essay Flexible and Rigid Constitutions, Bryce proposed a new classification of constitutions based on "(...) the relation which each Constitution bears to ordinary laws of the State and to the ordinary authority which enacts those laws."

In his view flexible constitutions:

" (..) are on the level of other laws of the country, or also in the form of recorded decisions defining and confirming a custom. Such Constitutions proceed from the same authorities which make the ordinary laws; and they are promulgated or repealed in the same way as ordinary laws"2 (...) "Technically, therefore, we cannot draw a distinction between constitutional and other laws."

On the other hand rigid constitutions:

"(...) stand above the other laws of the country which they regulate. The instrument (or instruments) in which such a constitution is embodied proceeds from a source different from that whence spring the other laws, is repealable in a different way, exerts a superior force. It is enacted, not by the ordinary

\footnotetext{
1 James Bryce, Constitutions 7 (Oxford University Press 1905).

2 Id. at 7-8.

3 Id. at 12.
} 
legislative authority, but by some higher or specially embodied person. If it is susceptible of change, it can be changed only by that authority or by that special person or body. When any of its provisions conflicts with a provision of the ordinary law, it prevails, and the ordinary law must give away."

In Bryce's conception, ${ }^{4}$ a constitution can be deemed rigid when its amendment procedure is more complicated than the one employed for ordinary laws. Consequently, such a constitution has a different nature and stands above the laws of the country. On the other hand, a flexible constitution can be amended by the same procedure as an ordinary law and thus does not have a special formal hierarchy. Bryce did not make a distinction based solely on the amendment procedure, but rather on the nature of such constitutions vis-à-vis the ordinary law. ${ }^{5}$

According to Bryce, each type of constitution has different strengths and weaknesses. In this regard, flexible constitutions are by nature elastic, which may add stability and balance to the fundamental norm. In this sense, "[j] ust because their form is not rigidly fixed, a temporary change is not felt to be a serious change" allowing them to recover from a crisis without injury. They can minimize the risks of open confrontation or revolutionary movements. Adaptation is their keyword. However, this flexible nature may become a weakness in itself because, to a certain extent, it may give way to the abuse of its ability to change. This peculiarity becomes more evident when Parliament has the power to singly amend the constitution like an ordinary law and party discipline leads to an overwhelming concentration of power. Rigid constitutions have the stability of political institutions and the advantage of having their explicit confirmation in a written text. However, the same stability that characterizes them can prove to be a weakness at certain times for in their rigidity there is an element of danger. ${ }^{7}$ Bryce states that:

"When a party grows up clamoring for some reforms which can be effected only by changing the Constitution, or when a question arises for dealing with which the Constitution provides no means, then, if the Constitution cannot be amended in the legal way, because the legally prescribed majority cannot be obtained, the discontent that was debarred from any legal outlet might find vent in a revolution or a civil war. The Constitution of the United States illustrates this danger on so grand scale that no other illustration is needed."

Bryce's brilliant distinction has been slowly fading away although it remains as a paradigm in classic constitutional theory. ${ }^{9}$ The reasons for this "fading" may well be that flexible constitutions are now rather the exception.

\footnotetext{
4 Id. at 8.

5 Alessandro Pace, Starre und flexible Verfassungen, 49 Jahrbuch des öffentlichen Rechts der Gegenwart 90 (2001).

6 See BRYCE, supra note 1 at 22.

7 Id. at 67.

$8 \quad$ Id. at 68.

9 Further considerations inter alia in Edward David, The Community's constitution- Rigid or Flexible? The Contemporary Relevance of the Constitutional Thinking of Fames Bruce, in InstitutionaL
} 
Other than the English Constitution, we cannot really argue that the category is still useful for practical purposes. On the other hand, other distinctions have been debated and employed, such as legal sanctions vs. political sanctions regarding the breach of constitutional provisions ${ }^{10}$ (partially on Kelsenian grounds ${ }^{11}$ on the element of sanction).

\section{Formally rigid, materially flexible}

Having revisited Bryce's analysis, it is possible to answer the following question: is the Mexican Constitution rigid or flexible? In this regard, Mexico's Constitution would undoubtedly fall under the rigid category.

Its legislative procedure is established in Articles 71 and 72 of the Constitution. The procedure may be initiated by the President, Federal Deputies, Senators or $0.13 \%$ of the voters list (a popular initiative). In broad terms, except in the case of certain matters, both congressional chambers might serve as an origin and a revising chamber. Once approved by one chamber, the bill is passed on to the revising chamber. If the second chamber has no objections, the bill is immediately published. In case of observations, the bill would be returned to the origin chamber for renewed discussion. When a bill is finally approved by both chambers, it is sent to the President of the Republic. Within 30 days, the President can either veto or publish the law. A veto may only be overridden by a majority of $2 / 3$ in both chambers.

The fact that the natural majority required for constitutional amendments is already 2/3 makes a strong case regarding the statement that amending a constitution is more complicated than amending an ordinary law. Furthermore, the participation of federal entities (which must also consent to the amendment) is a determining factor. Its rigidity is undisputable. Nonetheless, Bryce's analysis can be considered a normative one. He focuses on the nature of the constitution regarding its hierarchical difference to ordinary laws, reinforced by a different amendment procedure. However, he implicitly excluded from his analysis the behavior of the political system and the actual usage of amendments.

In this sense, even if the Mexican Constitution is apparently a rigid constitution, it has acted in practice as a materially flexible constitution. So far (February 8, 2016), the Constitution has been amended through 227 amendment decrees. Each decree often amends more than one article, which gives us more than 650 individual changes to the constitution. Only 22 articles stand without any amendment. That means 114 articles have been amended,

Dynamics of European Integration: Essays in Honour of Henry G Schermes 63, 73 (D. Curtin and T. Heukels eds., 1994).

10 Pasquale Pasquino, Classifying Constitutions: Preliminary conceptual analysis, 34:999 Cardozo L. Rev. 1016, 1017 (2013).

11 Hans Kelsen, La garantie juridictionnelle de la Constitution, 35 Revue du Droit Public et de la Science Politique (1928). 
Esta revista forma parte del acervo de la Biblioteca Jurídica Virtual del Instituto de Investigaciones Jurídicas de la UNAM

roughly the $84 \%$ of the Constitution. Paradoxically, even the amendment procedure set forth in Article 135 has been amended. Is it even a valid question to ask whether or not our current Constitution is actually the one enacted in $1917 ?^{12}$

In the period between 2012 and 2015, the rate of amendments has stood at 6.6 amendment decrees per year; that is, a decree amending several articles every two months. These amendments have not only changed the text, but they have also substantially enlarged it. Therefore, the length of the Constitution has almost doubled in size. ${ }^{13}$

The tendency is increasing. From 1917 to 1979 (62 years), the Constitution was amended through 90 amendment decrees. However, from 1980 to February 2016, the Constitution was amended 137 times in only 36 years. The rate of amendments is truly impressive if compared with other countries like the United States (27 amendments in 227 years), Spain (2 amendments in 38 years), Poland (2 amendments in 25 years) and so on.

In conclusion, the Mexican Constitution can only be deemed rigid from a normative perspective in terms of procedure. The practice of decreeing amendments, on the other hand, shows it to be a flexible, easily amendable Constitution, which frequently invades the natural scope of statutes and ordinary provisions through the regulation of constitutional text matters with an unusually deep level of detail while preserving its hierarchical nature vis-à-vis ordinary laws (reinforced by constitutional justice mechanisms).

The following table represents the constitutional amendments made to the 1917 Constitution divided by presidential periods:

\begin{tabular}{|c|c|c|c|}
\hline Period & President & $\begin{array}{c}\text { Number of } \\
\text { amendments }\end{array}$ & $\begin{array}{c}\text { Average } \\
\text { amendments } \\
\text { per year }\end{array}$ \\
\hline $1917-1920$ & Venustiano Carranza & 0 & 0 \\
\hline $1920-1924$ & Álvaro Obregón & 2 & 0.5 \\
\hline $1924-1928$ & Plutarco Elías Calles & 5 & 1.25 \\
\hline $1928-1930$ & Emilio Portes Gil & 1 & 0.5 \\
\hline $1930-1932$ & Pascual Ortiz Rubio & 2 & 1 \\
\hline $1932-1934$ & Abelardo L. Rodríguez & 9 & 4.5 \\
\hline $1934-1940$ & Lázaro Cárdenas & 10 & 1.66 \\
\hline $1940-1946$ & Manuel Ávila Camacho & 10 & 1.66 \\
\hline $1946-1952$ & Miguel Alemán Valdés & 13 & 2.16 \\
\hline $1952-1958$ & Adolfo Ruiz Cortines & 1 & 0.16 \\
\hline $1958-1964$ & Adolfo López Mateos & 8 & 1.33 \\
\hline
\end{tabular}

12 See Diego Valadés, La Constitución Reformada 11, (IIJ-UNAM 1987).

13 José María Soberanes, Análisis formal de las reformas constitucionales 3 (IIJUNAM, 2015). 
Esta revista forma parte del acervo de la Biblioteca Jurídica Virtual del Instituto de Investigaciones Jurídicas de la UNAM

\begin{tabular}{|c|c|c|c|}
\hline Period & President & $\begin{array}{c}\text { Number of } \\
\text { amendments }\end{array}$ & $\begin{array}{c}\text { Average } \\
\text { amendments } \\
\text { per year }\end{array}$ \\
\hline $1964-1970$ & Gustavo Díaz Ordaz & 8 & 1.33 \\
\hline $1970-1976$ & Luis Echeverría & 15 & 2.5 \\
\hline $1976-1982$ & José López Portillo & 14 & 2.33 \\
\hline $1982-1988$ & Miguel de la Madrid & 19 & 3.16 \\
\hline $1988-1994$ & Carlos Salinas & 15 & 2.5 \\
\hline $1994-2000$ & Ernesto Zedillo & 18 & 3 \\
\hline $2000-2006$ & Vicente Fox & 17 & 2.83 \\
\hline $2006-2012$ & Felipe Calderón & 38 & 6.33 \\
\hline $2012-$ present & Enrique Peña Nieto & 22 & $5.17^{14}$ \\
\hline
\end{tabular}

Figure 1. Source: Author

\section{Consequences and problems of hyper-reformism}

A constitution that is amended every two months evidently generates various problems. In the first place, it hinders the consolidation of the constitutional text. Articles and concepts do not gain the strength and prestige that somehow is attributed to other constitutional texts aided by constant interpretation through the years. In second place, the text is visibly deficient. Numerous mistakes, grammatical errors and terminological imprecisions can be detected in a Grundnorm, the prestige of which should be beyond question. In third place, as I have pointed out elsewhere, ${ }^{15}$ continuous invasive amendments contravene the development of local constitutionalism (constitutional development of Federal Entities). Lastly, constant amendments and changes in fundamental institutions have an impact not only in economic terms, but also in terms of the stability of the institutions themselves. Not only has the State frequently assumed massive costs in changing institutions (IFE to INE, for example) but also those institutions do not consolidate through mature development and practice.

Professor Valadés and Professor Fix Fierro have jointly coordinated an interesting project on the organization and consolidation of the Mexican Constitution. ${ }^{16}$ The project argues that even though the constitution has been modernized through amendments that incorporate elements of contemporary constitutionalism. These amendments have produced a long, unsystematic

14 I use a period of 4.25 years. Counting a full year in December (in which the current President took office) or January and February 2016 would distort the results.

15 Mauro Arturo Rivera, Las otras constituciones: el constitucionalismo local en la encrucijada de la reforma constitucional, in Miradas a la Historia Constitucional De México 221, 242 (Catherine Andrews et al eds., 2015).

16 The full project is available at http://biblio.juridicas.unam.mx/libros/9/4050/1.pdf 
and somewhat chaotic text. This is by no means a new assessment, but it is a precise one. The problems of the constitution are well known to those who have witnessed the relatively recent debate on amending the text versus creating a new Constitution. ${ }^{17}$ The virtue of the project lies precisely in its desire to leave the fundamental decisions untouched and to aim only at the methodological and grammatical problems of the text (i.e. a reformulation under legal drafting principles and not a new text in itself).

The authors identify the following problems: ${ }^{18}$ 1) Duplicated articles. For example, Article 130 forbids ministers of religion to hold public office. However, the same provision is subsequently repeated in other articles regarding specific offices, as Deputy or President. 2) Inconsistent use of terminology. For example, the constitution employs the terms "human rights" (Art. 1) and "fundamental rights" somewhat indistinctly. Another example would be the use of the word "autonomy" regarding constitutional autonomous bodies which lacks systematic treatment. 3) Disparity in the length of the regulation on different matters. For example, while the regulation of the Federal Electoral Court occupies a full article of more than 1000 words, labor and military justice (Art. 123 and 13) take only few lines. 4) A lack of order and a system of topics regulated by the Constitution. There are several articles in the constitution that do not respect the proper homogeneity of subjects. The contents of several articles could be placed more properly in other articles. 5) The deficient placement of constitutional provisions. For example, human rights institutes are placed in the article regulating the Office of the Public Prosecutor and the Attorney General. Moreover, the dogmatic part of the constitution (which traditionally regulates rights) sets forth the regulation of different organisms, such as the National Institute for Education Assessment, National Institute for Transparency, Access to Public Information and Personal Data Protection, National Institute of Geography, Statistics and Informatics, Federal Antitrust Commission, and so on. 6) Mistakes in the constitutional text. Before the amendment of January 2016, there were mistakes in the terminology used for the names of the institutions of former Federal District (now Mexico City). Finally, we also have 7) Articles with a regulatory nature that actually function as secondary regulations in various areas, as in the case of Article 41, which regulates electoral administration, or Article 20, which regulates various aspects of criminal procedure and human rights. I will deal at length with this topic below.

Professors Valadés and Fix Fierro propose a consolidated version of the text which does not alter the content, but improves its form. The organization of the text is also enhanced as diverse normative portions are relocated to more appropriate articles. Finally, to attend the regulatory nature of some constitutional articles, the professors propose the creation of a "Constitutio-

17 See Jorge Carpizo, ¿Se necesita una nueva Constitución en México? Algunas reflexiones y seis propuestas, 24 Cuestiones Constitucionales 141, 167 (2011).

18 Here we follow in toto the study of VaLADÉs \& Fierro, supra note 16. 
nal Development Law" (Ley de desarrollo constitucional). Such law would need to be approved by $2 / 3$ of the Congress and operate under a more flexible procedure than that for constitutional amendment, which requires the additional approval of the majority of the states. The project also proposes that the Supreme Court analyze the constitutionality of such a law. This law aims to shift regulatory provisions from the constitution to the constitutional development law.

This project provides a very good explanation about the subtleties of Mexican political conditions. In my view, even though is arguable whether or not a new Constitution could technically be a better solution to the problems in the text, the current political conditions are not favorable for a new Constitution. Presumably, political actors would not dare to open Pandora's Box and question the fundamental political agreements that uphold the rules of the constitutional system.

Even though the proposed solution is a technically viable solution, it is necessary also to identify and solve the causes of the rate of amendments. Otherwise, political dynamics could start fostering unnecessary amendments by altering the corrected text.

\section{II.THE AMENDMENT PROCEDURE}

\section{An historical overview}

Throughout Mexican constitutional history, the various Constitutions have formulated different amendment procedures. The first Constitution in force in Mexico was the 1812 Constitution of Cadiz. ${ }^{19}$ The amendment procedure established in this constitution was rather complicated (Articles 377-384). At least 20 deputies are required to propose an amendment. The text must be read three times over a period of six days to consider the merits of the proposal in order to decide whether or not to formally open discussion on the amendment. If the amendment is approved at least by a 2/3 vote, it could be discussed further by the next legislature. The next legislature needs to approve the powers to amend the Constitution by a $2 / 3$ vote. If the next legislature approves the amendment by a $2 / 3$ vote, the electoral board of the provinces would determine if the current legislature or the next one needs to approve the proposed amendment again by a $2 / 3$ vote. This procedure is extremely rigid and complicated.

The Constitution of Apatzingan (The Constitutional Decree for the Liberty of Mexican America) was conceived as a provisional Constitution and therefore did not establish an amendment procedure. It even prohibited any amendment especially one regarding the system of government (Art. 237).

19 Javier Tajadura, La problemática de los límites del poder de reforma constitucional en la Constitución de Cádiz, 13 Historia Constitucional 267 (2012). 
In view of this prohibition, did the Constitution of Apatzingan assume that other matters could also be amended? And, if so, under which procedure? Given the preeminence given to the legislative branch in this Constitution, it could very well be that it was assumed that the same procedure used to create and amend ordinary laws would be employed. However, this argument is highly theoretical as Article 237 announces the creation of a new Constitution by the "National Representation", which could presumably establish a different amendment procedure ex novo.

The 1824 Federal Constitution (Articles 166-171) adopted an amendment procedure that required the consecutive approval of two legislatures. The right of initiative belonged only to the states. States could propose amendments which would be analyzed by the current legislature, but voted on by the following one. This procedure did not required special majorities. According to Article 171, principles concerning freedom, sovereignty, religion, the system of government and the division of powers among the Federation and the states were unamendable.

The 1836 centralist Constitution (also called the Seven Laws) employed the term "Variation of Constitutional Laws". This procedure (Articles 1-6 of the Seventh Law) was employed for ordinary laws with one exception. A "Variation of Constitutional Laws" required the approval of the Supreme Conservative Power (Article 12.10 of the Second Law). The Supreme Conservative Power was a body that could control the constitutional consistency of the other branches. It is not clear whether this approval was meant as a formal requirement or the body truly had such margin of political decision that it could influence constitutional amendments.

Finally, the current procedure was adopted in 1857. Article 127 of the 1857 Constitution required that amendments had to be approved by $2 / 3$ of the present members of the Congress and by a simple majority of the states. The text of Article 127 was adopted almost in its entirety to become Article 135 of the 1917 Constitution. The changes are minor. Article 135 incorporated some accents, presumably as part of certain spelling changes in the Spanish language. It also changed the word "Constitution" for "misma" [the same] in the second phrase, serving as an anaphoric reference or a pronoun. Lastly, it added a comma in the last sentence. As can be observed, these minor changes are only stylistic and in no way modified the substance of the procedure. Therefore, it is possible to argue that Mexican constitutionalism already has 159 years of experience using the same constitutional amendment procedure. It is worth exploring the amendments made to the 1857 text.

In 60 years, the 1857 Constitution was amended 34 times ${ }^{20}$ which gives a rate of 0.56 amendments per year. This is a much lower rate than that made to the current Mexican Constitution and still substantially inferior than the rate of 1.17 amendments per year during the first 20 years of the 1917 Constitution.

20 Imer B. Flores, La Constitución de 1857 y sus reformas: a 150 años de su promulgación, in El proceso constituyente mexicano: a 150 aÑos de la Constitución de 1857 y 90 de La Constitución de 1917 320, 324 (Diego Valadés \& Miguel Carbonell eds., 2007). 


\section{The "main" amendment procedure}

It is a commonly shared thought that the amendment procedure is solely described in Article 135 of the Constitution. However, as Professor Valadés has argued, there is more than one procedure for amending the constitution.

The main constitutional amendment procedure is described in Article 135 of the Constitution. In this procedure, the Congress of the Union must approve the amendments by a vote of $2 / 3$ of the present members. The amendments must subsequently be approved by the majority of the states.

This procedure has been amended twice in history. The first one took place in 1966 and allowed the Permanent Committee to perform certain functions in state vote counting. Presumably, before the amendment, only the Congress could count votes and thus, the promulgation of constitutional amendments was consequently at a standstill during Congress recesses. The original text of the 1917 Constitution established only one period of ordinary sessions ${ }^{21}$ from September $1^{\text {st }}$ to December $31^{\text {st }}$ (even though it could be ended earlier upon agreement). Such short periods could have motivated the amendment in order to speed up the process.

In second place, Article 135 was further amended in 2016 as to expressly include "Mexico City" in the amendment procedure. Originally, Mexico City was considered a Federal District hosting the capital and the federal branches of power. Given the fact that the amendments were voted on by the "majority of the states", Mexico's capital was consequently excluded from the amendment procedure. In 2016, an amendment covering 52 articles in the Constitution changed Mexico's Federal District into the $32^{\text {nd }}$ Federal Entity. Among these changes was the express inclusion of Mexico City in the amendment procedure. However, deficient legal drafting may raise questions as to its interpretation. Currently, Article 135 states:

"The present Constitution may be added to or amended. In order that the additions or amendments shall become a part thereof, it shall be required that the Congress of the Union, by a vote of two thirds of the individuals present, agree to the amendments or additions and that they be approved by a majority of the legislatures of the States and of Mexico City. The Congress of the Union or the Permanent Committee, as the case may be, shall count the votes of the legislatures and shall announce those additions or amendments that have been approved".

Given the wording, does it declare that amendments need to be approved by the majority of the Federal Entities formed of states and Mexico City, or has Mexico City been granted the power to give its approval independently? The original text in Spanish says "...y que éstas sean aprobadas por la mayoría de las legislaturas de los Estados y de la Ciudad de México.” Naturally, the original intention was to add Mexico City to the group of Federal Entities whose approval is required for an amendment and not to grant Mexico City

21 Gonzalo Campos, Ampliación de los periodos de sesiones ordinarias del Congreso Federal, 89 Quorum 72 (2007). 
separate powers of approval. A better technique would have simply been to state that "...they be approved by a majority of the Federal Entities" thus including Mexico City without the need to mention it expressly.

Article 135 does not specifically mention who has the right to propose constitutional amendments. This has led to a consolidated doctrine which states that the right of initiative for constitutional amendments is the same as the one for ordinary laws.

Historically, Article 71 said that the right to initiate laws belonged to the President of the Republic, Federal Deputies, Federal Senators, and state legislatures. However, in 2012, the constitution was amended as to establish a popular initiative consisting of $0.13 \%$ of the voter registry list. If the same people who can propose a bill can also propose a constitutional amendment, can it be said that there is now a popular right of initiative for constitutional amendments? The answer seems to be yes. There are no grounds to exclude popular initiative from constitutional amendments if it is considered that an initiative of this type is the same as that for ordinary laws. Also, besides an express mention in Article 135, Article 71 included Mexico City in January 2016 as a party that is able to propose laws through its legislature.

Presidential veto is not admissible for constitutional amendments. As I have previously stated, ${ }^{22}$ there are at least three commonly argued reasons why a veto cannot be used. In the first place, it is not an express right attributed to the President. Therefore, to exercise veto against a constitutional amendment would be a breach of the principle of legality. Secondly, under the Court theory of the "amendment body of the Constitution", constitutional amendment as a constituent power could not be controlled by an elected official like the President (a weaker argument). Finally, there is a practical argument. Legislative veto may be overridden by a $2 / 3$ vote. If constitutional amendments already require a $2 / 3$ vote, it would be illogical for the presidential veto to demand the same vote that was already required. The same majority would be compelled to override the veto. ${ }^{23}$

\section{Territorial constitutional amendment procedures ${ }^{24}$}

We have briefly analyzed Article 135, deemed by many as the only amendment procedure. However, we must also consider other procedures that have

22 Mauro Arturo Rivera, De la rigidez teórica a la flexibilidad material: un análisis del procedimiento de reforma constitucional en México (1917-2012), Revista Iberoamericana de Derecho Procesal Constitucional 171, 195 (2013).

23 This argument is similar to the one stated in Hollingsworth vs State of Virginia (3 US 378).

24 Several authors have claimed that there are only two constitutional amendment procedures, thus arguing implicitly that the territorial procedures are just variations of a territorial amendment procedure. Miguel Carbonell, Notas sobre la reforma constitucional en México, 245 Revista de la Facultad de Derecho de México 229 (2006). Also Miguel Eraña, Las minorías parlamentarias en la reforma constitucional, 33 Anuario del Departamento de Derecho de la Universidad Iberoamericana 155, 156 (2004). I firmly believe that Sections II and II are in fact different amendment procedures. 
been established to change the composition of national territory. These procedures are established as part of the legislative powers of the Federal Congress, described in Article 73, Sections I and III.

The territory of the Federation is expressly described in Articles 42, 43 and 44 . Article 42 of the Constitution describes the territory in toto. Article 43 enumerates the states of the Federation. Finally, Article 44 establishes Mexico City as a Federal Entity and the capital of the nation.

The dilemma is clear. If Article 73 sets forth procedures to amend the territory of the Federation and this territory is expressly described in the Constitution, there are only two options to consider: either the Constitution describes two procedures which cannot be used at all because they would still require a subsequent constitutional amendment, or the Constitution is expressly describing two additional procedures to amend the Constitution in the specific area of territorial composition. I presume that the latter is the correct one. I agree with Professor Valadés's ${ }^{25}$ assessment: "Therefore, in each of the fractions of article 73 (...) we find other hypotheses of constitutional amendments different to the one contained in Article 73." Other authors have maintained different opinions.

The constitution must be interpreted systematically. Territorial procedures allow at least an amendment of Articles 42, 43 and 44. Further amendments could be discussed. For example, if the intention of an amendment were to divide the territory of the State of Nayarit, could we not assume that, by analogy, this procedure allows the amendment of Article 47 of the Constitution as well, which states that "The State of Nayarit shall have the territorial area and boundaries which at present comprise the Territory of Tepic?" Further debates could be raised on whether or not those procedures might eventually include "Mexico City", even though it is Federal Entity and not a state.

The abovementioned discussions, however, should be deemed as merely theoretical disputes. As I shall argue, the territorial procedures have never been used under the 1917 Constitution. All territorial amendments have been performed following the generic procedure described in Article 135.

\section{A. The flexible territorial procedure}

Article 73.I states that the Congress has the power "[t]o admit new States into the Federal Union." As I have argued before, accepting a hypothetical new state to the Union would necessarily imply at least one amendment to Article 43, which exhaustively describes the States that form the Federation.

This amendment procedure however is flexible ${ }^{26}$ and it is entirely vested in the Federal Congress. Such an amendment procedure requires neither a

25 VALADÉs, supra note 12 at 17.

26 Valadés himself clearly pointed out that Article 73.I "authorizes the Congress to amend the Constitution. In this case, we have a flexible amendment procedure." Id. 
special majority nor further approval from the remaining Federal Entities. Here, there is a case in which a constitutional amendment can be approved in the same way as ordinary legislation is. Questions may arise as to whether or not the President may use the power of veto. In this case, the ability to force a further voting under a 2/3 majority would actually have practical effects as the majority under the veto conditions would be greater than the original majority. National doctrine provides no answer for this question. If we consider that a veto may not be exercised, we would have a clear case in which amending the Constitution would be even easier than amending an ordinary law.

Political conditions, however, are quite clear. These hypotheses apply only to new states, which are by definition not already part of the Federation. For this section to be exercised, it is necessary for neighboring nations or overseas countries to ask to become part of Mexico. Both cases are very unlikely.

This section was amended once in 1974 . Originally, the section stated that the Congress had power " $[\mathrm{t}] \mathrm{o}$ admit new States and Territories into the Federal Union". With the end of the "territory" regime, this part of the provision was repealed.

\section{B. Converting territories into states: The repealed conversion procedure}

Before 1974, Mexico was divided into both states and territories. Territories were portions of land whose political and economic conditions did not meet the conditions to achieve the self-determination of a state and thus had a lesser political autonomy. The territories originally mentioned in the 1917 Constitution were the territories of Baja California and Quintana Roo. A detailed description of the evolution of former Mexican territories goes beyond the scope of this article. It should be said nonetheless that in 1974, the last territories (Quintana Roo and Baja California Sur) were admitted as states and Section II of Article 73 was repealed.

The original text of the 1917 Constitution established that Congress had the power " $[\mathrm{t}]$ o convert Territories into States when they have a population of eighty thousand inhabitants and the necessary resources to provide for their political existence." Just as with the abovementioned section, this provision is a flexible amendment procedure which requires only the approval of Congress.

The procedure was never used even in the cases in which the conversion was achieved. For example, in 1952, the territory of Baja California Norte was converted into a State using the procedure established in Article 135, which involved the approval of the other Federal Entities. The same occurred in 1974 when the territories of Baja California Sur and Quintana Roo ascended to the category of state, again under the procedure of Article 135 instead of this specific procedure. 
The problems of using the generic procedure contained in Article 135 instead of the flexible one in Sections I and II (repealed) of Article 73 are not important. By using Article 135, the amendment is carried out by a procedure with even more guarantees. Furthermore, Congress actually has mandatory intervention in the abovementioned sections. Therefore, it would not be possible to claim that the 1974 amendments that turned territories into states are void because, in addition to the procedure of Article 73.II, a greater majority was required and subsequently approved by the Federal Entities. The real problem may arise with the next procedure.

\section{The ultra-rigid territorial division procedure}

From all the territorial procedures, the most rigid one is undoubtedly the one described in Article 73.III, which grants power to the Congress "[ $\mathrm{t}] \mathrm{o}$ form new states within the boundaries of existing ones." This procedure contemplates two scenarios depending on whether the state or states to be divided consent to such division.

If the division is endorsed by the interested parties, a 2/3 majority of the Congress is required, plus the approval of the majority of the states. The President is also to be heard to prove before the Congress that there are elements that support the political existence of the new states and that the area(s) seeking to be made a state have a population of at least 120,000 habitants. Given the fact that a 2/3 vote of the Congress and a majority of the states is required, the audience given to the President makes this case arguably more rigid than the procedure contained in Article 135.

However, Article 73.III.7 establishes that in the absence of the abovementioned consent, the approval of the Federal Entities requires a 2/3 majority, far greater than that required by the procedure of Article 135. Procedurally speaking, it is more complicated in Mexico to divide a state without its consent than to amend human rights or change the system of government.

Given the fact that the territorial procedures have been simply ignored, this raises the question: what would happened if the Congress tried to divide a state or states without their consent by using the procedure of Article 135 and not the one in Article 73.III? In this case, contrary to Sections I and II, I believe that a constitutional breach could be claimed since using the "generic procedure" would provide considerably fewer guarantees than the specific provision for territorial division.

It must still be noted that the consolidation of the territorial architecture of the Republic makes this scenario highly unlikely. The territory of the Federation has been consolidated and there has been no discussion about dividing states in the public sphere and it does not seem feasible one will arise in the near future. 
It is very interesting to note that before 1917 a similar procedure was established in Article 72.III of the 1857 Constitution. This procedure, however, did not increase the requirements in case of an absence of consent and only required congressional approval and the consent of a simple majority of the states. Therefore, contrary to our current territorial division procedure, the one in the 1857 Constitution was flexible. This procedure was indeed used three times during the period in which the 1857 Constitution was in force. ${ }^{27}$ These amendments may be the only case of the use of a constitutional procedure other than the one contained in Articles 135 (1917 Constitution) and 127 (1857 Constitution) in the last 159 years.

\section{Bryce and the capacity of constitutions for territorial expansion}

Before finishing the analysis of territorial amendments in the Mexican Constitution, it should be noted that Bryce briefly analyzed the capacity for territorial expansion as an asset of flexible constitutions. Given the fact that it has already been stated that territorial amendment procedures are flexible in nature, it should also be considered whether territorial expansion considerations played any role at all in the drafting of the relevant 1857 constitutional provisions, which were somewhat inherited by the 1917 Constitution.

Bryce considered the potential expansion of states by conquest or through a treaty a characteristic of the suitability of flexible constitutions in some cases. Even though his analysis never considered the possibility that a constitution may have different amendment procedures for different purposes, the observation is precise and deserves more consideration. In his view, "[s]uch constitutions [flexible constitutions] seem especially well suited for countries which are passing through periods of change whether internal or external. ${ }^{9}, 28 \mathrm{He}$ quotes the examples of Rome and England whose constitutional flexibility allowed for territorial change "(...) in both cases altering the Constitution of the enlarged State no further than by the admission of additional members to the two Houses of Parliament..." ${ }^{29}$ As I have already pointed out, this exact procedure (the approval of the two Houses of Parliament) is established under some of the premises of the territorial amendment procedures contained in Article 73.

It is well known that Mexico went through major territorial changes before 1857, most significantly, the loss of half of its territory in a war against the United States through the treaty of Guadalupe-Hidalgo in 1848. After that, as I have already pointed out, other territorial changes occurred regarding the nature of the former "territories" and their conversion into states. Previous constitutions, such as the 1824 Federal Constitution, the 1836 centralist

27 FLORES, supra note 20 at 292, 293.

28 BRYCE, supra note 1 at 43. Italics are mine.

29 Id. at 44. 
Esta revista forma parte del acervo de la Biblioteca Jurídica Virtual del Instituto de Investigaciones Jurídicas de la UNAM

Constitution (the "Seven Laws") or the Organic Bases of the Mexican Republic in 1843, did not mention anything about territorial amendments, despite containing provisions on territorial distribution.

In this regard, I think territorial adaptation could have played a significant role in the 1857 Constitution in attempting to confer a desired flexibility to procedures pertaining to the territorial organization of the State.

\section{Causes of the HyPeR-Amendment}

Mexican Constitution will be a hundred years old in 2017, with more than 650 changes through 227 amendment decrees. It was previously stated that, given the fact that Article 135 of the 1917 Constitution was substantially the same as Article 127 of the 1857 Constitution, it could even be argued that Mexican Constitutionalism has already had 159 years with the same constitutional amendment procedure; 159 years through which amendments have always and steadily increased in frequency, size and rate. The following graph may explain this:

\section{Average amendments per year}

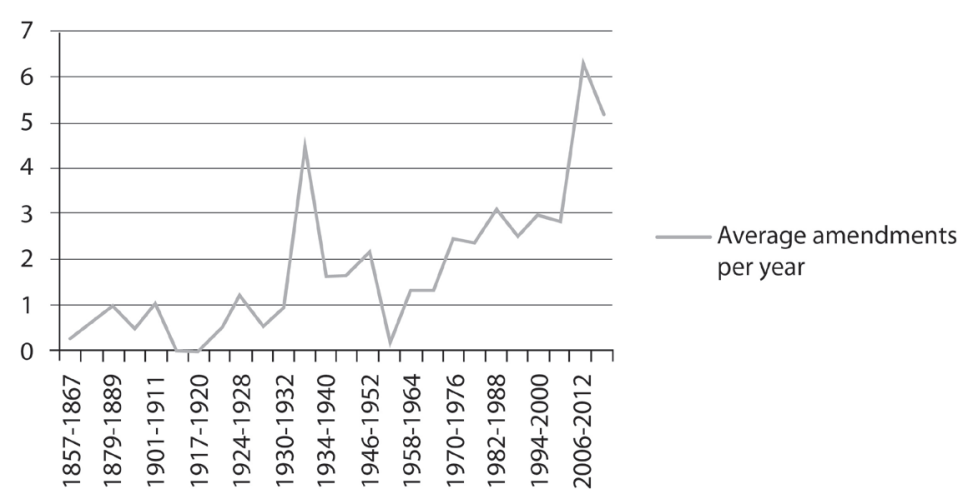

Much has been discussed about the effects of such amendments and the political conditions which motivated them, but what are the real causes of this rate? In the following sections, I argue that no single cause may fully account for this. Several causes must be analyzed jointly, namely the former hegemony of a single political party, the political conception of the Constitution, the regulatory nature of some constitutional provisions and a progressive centralization of powers. 
Political Composition of the Mexican Chamber of Deputies (1994-2015)*

\begin{tabular}{|c|c|c|c|c|c|c|c|c|c|c|c|c|}
\hline $\begin{array}{l}\text { Yearl } \\
\text { Party }\end{array}$ & PRI & $P A \mathcal{N}$ & $P R D$ & $P T$ & $P V$ & $C V$ & $\mathcal{N} A$ & $M C$ & $A$ & $M$ & PES & President \\
\hline $1994 * *$ & $\begin{array}{c}300 \\
(60 \%)\end{array}$ & $\begin{array}{c}119 \\
(23.8 \%)\end{array}$ & $\begin{array}{c}71 \\
(14.2 \%)\end{array}$ & $\begin{array}{c}10 \\
(2 \%)\end{array}$ & & & & & & & & $\begin{array}{l}\text { Ernesto } \\
\text { Zedillo }\end{array}$ \\
\hline 1997 & $\begin{array}{c}239 \\
(47.8 \%)\end{array}$ & $\begin{array}{c}121 \\
(24.2 \%)\end{array}$ & $\begin{array}{c}125 \\
(25 \%)\end{array}$ & $\begin{array}{c}7 \\
(1.4 \%)\end{array}$ & $\begin{array}{c}8 \\
(1.6 \%)\end{array}$ & & & & & & & $\begin{array}{l}\text { Ernesto } \\
\text { Zedillo }\end{array}$ \\
\hline 2000 & $\begin{array}{c}211 \\
(42.2 \%)\end{array}$ & $\begin{array}{c}207 \\
(41.4 \%)\end{array}$ & $\begin{array}{c}50 \\
(10 \%)\end{array}$ & $\begin{array}{c}7 \\
(1.4 \%)\end{array}$ & $\begin{array}{c}17 \\
(3.4 \%)\end{array}$ & $\begin{array}{c}3 \\
(0.6 \%)\end{array}$ & & & & & & $\begin{array}{l}\text { Vicente } \\
\text { Fox }\end{array}$ \\
\hline 2003 & $\begin{array}{c}224 \\
(44.8 \%)\end{array}$ & $\begin{array}{c}151 \\
(30.2 \%)\end{array}$ & $\begin{array}{c}97 \\
(19.4 \%)\end{array}$ & $\begin{array}{c}6 \\
(1.2 \%) \\
\end{array}$ & $\begin{array}{c}17 \\
\left(3.4^{\%} \%\right) \\
\end{array}$ & $\begin{array}{c}5 \\
(1 \%)\end{array}$ & & & & & & $\begin{array}{l}\text { Vicente } \\
\text { Fox }\end{array}$ \\
\hline 2006 & $\begin{array}{c}106 \\
(21.2 \%)\end{array}$ & $\begin{array}{c}206 \\
(41.2 \%)\end{array}$ & $\begin{array}{c}127 \\
(25.4 \%)\end{array}$ & $\begin{array}{c}11 \\
(2.2 \%)\end{array}$ & $\begin{array}{c}17 \\
(3.4 \%)\end{array}$ & $\begin{array}{c}17 \\
(3.4 \%)\end{array}$ & $\begin{array}{c}9 \\
(1.8 \%)\end{array}$ & & $\begin{array}{c}5 \\
(1 \%)\end{array}$ & & & $\begin{array}{c}\text { Felipe } \\
\text { Calderón }\end{array}$ \\
\hline 2009 & $\begin{array}{c}237 \\
(47.4 \%)\end{array}$ & $\begin{array}{c}143 \\
(28.6 \%)\end{array}$ & $\begin{array}{c}70 \\
(14 \%)\end{array}$ & $\begin{array}{c}13 \\
(2.6 \%)\end{array}$ & $\begin{array}{c}21 \\
\left(4.2^{\circ} \%\right) \\
\end{array}$ & $\begin{array}{c}6 \\
(1.2 \%)\end{array}$ & $\begin{array}{c}9 \\
(1.8 \%)\end{array}$ & & & & & $\begin{array}{c}\text { Felipe } \\
\text { Calderón }\end{array}$ \\
\hline 2015 & $\begin{array}{c}202 \\
(40.4 \%)\end{array}$ & $\begin{array}{c}108 \\
(21.6 \%)\end{array}$ & $\begin{array}{c}60 \\
(12 \%)\end{array}$ & & $\begin{array}{c}47 \\
(9.4 \%)\end{array}$ & & $\begin{array}{c}11 \\
\left(2.2^{\%} \%\right)\end{array}$ & $\begin{array}{c}25 \\
(5 \%)\end{array}$ & & $\begin{array}{c}35 \\
(7 \%)\end{array}$ & $\begin{array}{c}8 \\
\left(1.6^{\circ} \%\right)\end{array}$ & $\begin{array}{c}\text { Enrique Peña } \\
\text { Nieto }\end{array}$ \\
\hline
\end{tabular}

Table 2. Source: Author

* This tabla 2 represents the political composition of the chamber of the deputies. Deputies are elected for a 3 years term. Percentages may not sum $100 \%$ as I do not include

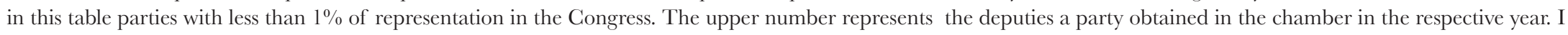

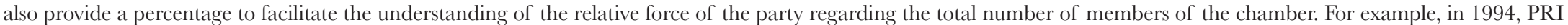

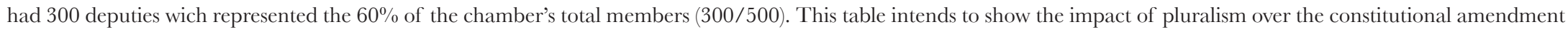

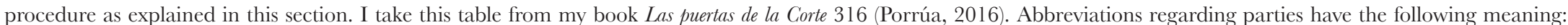

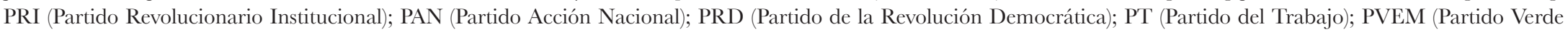
Ecologista de México); CV (Convergencia); MC (Movimiento Ciudadano); M (Movimiento Regeneración Nacional); PES (Partido Encuentro Social); NA (Nueva Alianza).

** Elections before 1994 were held with a 300-member Chamber of Deputies. From 1997 onwards, the Chamber increased its number to 500 with the inclusion of 200 deputies elected by proportional representation. 
Esta revista forma parte del acervo de la Biblioteca Jurídica Virtual del Instituto de Investigaciones Jurídicas de la UNAM

\section{The hegemony of a political party}

For a long time, it was a commonly shared idea that the frequent rate of constitutional amendments was a direct consequence of the dominance of a single political party. Since the PRI [Institutional Revolutionary Party] held close to $90 \%$ of the seats in both chambers and controlled all Federal Entities, amending the Constitution was regarded as party discipline. We should remember that it was not until 1989 that the PRI lost a gubernatorial election for the first time.

This hegemony can partially explain some of the amendments made in the period from 1917 to 1989, which witnessed a total of 117 amendments in 72 years, or a rate of 1.62 amendments per year.

Some Mexican academics viewed ${ }^{30}$ constitutional rigidity and fewer amendments as a natural consequence of greater pluralism. The transition period, which culminated in the PRI losing the presidency for the first time in 2000, would prove this hypothesis wrong

Political Composition of the Mexican Senate (1991-2012) ${ }^{31}$

\begin{tabular}{|c|c|c|c|c|c|c|}
\hline Year/Party & $P R I$ & $P A \mathcal{N}$ & $P R D$ & $P T$ & PVEM & $C V$ \\
\hline $1991^{34}$ & $\underline{\underline{61}}$ & $\begin{array}{c}1 \\
(1.56 \%)\end{array}$ & $\begin{array}{c}2^{*} \\
(3.12 \%)\end{array}$ & & & \\
\hline 1994 & $\underline{96}$ & $\begin{array}{c}24 * \\
(18.75 \%) \\
\end{array}$ & $\begin{array}{c}8 \\
(6.25 \%) \\
\end{array}$ & & & \\
\hline $\begin{array}{c}2000 \\
\mathrm{D}\end{array}$ & $(46.09 \%)$ & $\begin{array}{c}45^{*} \\
(35.15 \%) \\
\end{array}$ & $\begin{array}{c}17 \\
(13.28 \%) \\
\end{array}$ & $\begin{array}{c}1 \\
(0.007 \%)\end{array}$ & $\begin{array}{c}5^{*} \\
(3.9 \%) \\
\end{array}$ & $\begin{array}{c}1 \\
(0.007 \%)\end{array}$ \\
\hline $\begin{array}{c}2006 \\
\mathrm{MD} / \mathrm{D}\end{array}$ & $\begin{array}{c}35^{*} \\
(27.34 \%)\end{array}$ & $(40.62 \%)$ & $\begin{array}{c}31 \\
(24.21 \%)\end{array}$ & $\begin{array}{c}3 \\
(2.34 \%)\end{array}$ & $\begin{array}{c}4 \\
(3.12 \%)\end{array}$ & $\begin{array}{c}2 \\
(1.56 \%)\end{array}$ \\
\hline $\begin{array}{c}2012 \\
\mathrm{D}\end{array}$ & $\frac{52}{(40.62 \%)}$ & $\begin{array}{c}38 * \\
(29.68 \%)\end{array}$ & $\begin{array}{c}22 \\
(17.18 \%)\end{array}$ & $\begin{array}{c}5 \\
(3.9 \%)\end{array}$ & $\begin{array}{c}9 \\
(4.68 \%)\end{array}$ & \\
\hline
\end{tabular}

30 Carbonell, supra note 24 at 251.

31 This table 3 represents the political composition of the Senate. Senators are elected for a 6 years term. The upper number represents the number of senitors a party obtained in the Senate in the respective year. I also provide a percentage to facilitate the understanding of the relative force of the party regarding the total number of members of the senate. For example in 1994 PRI had 96 senators which represented the $75 \%$ of the Senate's total members (96/128). I take this table from my book Las puertas de la Corte 316 (Porrúa, 2016). For the abbreviations of the political parties, see the table regarding the chamnber of Deputies.

32 This was the last year in which the Senate consisted of 64 members. After this period, the Senate increased to 128 members. 
Esta revista forma parte del acervo de la Biblioteca Jurídica Virtual del Instituto de Investigaciones Jurídicas de la UNAM

\begin{tabular}{|c|c|c|}
\hline NA & MC & President \\
\hline & & Carlos Salinas \\
\hline & & Ernesto Zedillo \\
\hline & & Vicente Fox \\
\hline $1(0.007 \%)$ & & Felipe Calderón \\
\hline $1(0.007 \%)$ & $1(0.007 \%)$ & Enrique Peña Nieto \\
\hline
\end{tabular}

TABLE 3. Source: Author.

A comparison of the above data with the post-transitional amendments may yield surprising results. From 2000 to 2016, 80 amendment decrees were enacted, resulting in an average rate of 5 amendments per year. This data shows that during the period of pluralism, the number of amendments increased by more than $300 \%$.

In the case of the Chamber of Deputies, in recent years no single political party may amend the Constitution. And while it is true than in the periods of 2000-2006 and 2009-2012 two political parties (PRI and PAN) could obtain the 2/3 majority required, in the periods of 2006-2009 and 2012-2015 at least a three-political party agreement was required to amend the Constitution. A slightly different scenario can be observed in the Senate. From 2000 to date, a PRI/PAN agreement could always reach the required 2/3 majority.

Let us analyze the periods of greatest dispersal in which at least 3 political parties were required to amend the Constitution (2006-2009 and 2012-2015). In the 2006-2009 period the Constitution was amended 23 times, which results in an even greater rate of 7.66 amendments per year. Meanwhile, in the congressional period from 2012 to 2015, the Constitution was amended 22 times, which results in a rate of 7.33 amendments per year. The numbers clearly show the so-called hegemony hypothesis openly disproven. ${ }^{33}$

33 This graph reflects the amendments carried out over the last 5 legislatures in the Chamber of Deputies. The data is taken from the Chamber of Deputies database. http:// www.diputados.gob.mx/LeyesBiblio/ref/cpeum_crono.htm (12.04.2016). 
Esta revista forma parte del acervo de la Biblioteca Jurídica Virtual del Instituto de Investigaciones Jurídicas de la UNAM

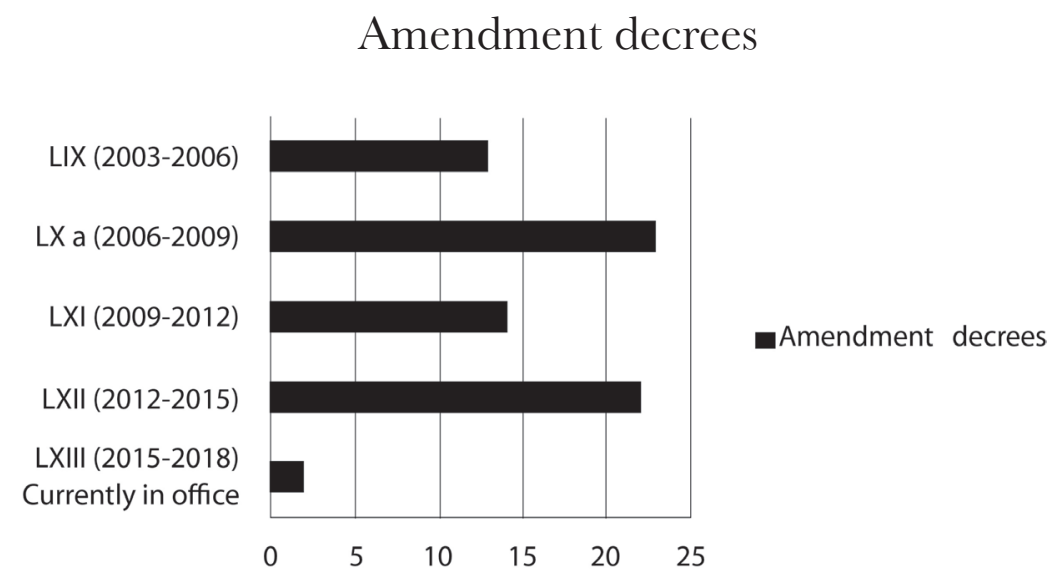

TABLE 2.

Not only has pluralism not slowed down the rate of constitutional amendments, but it has arguably increased it. Of course, as always, absolute theories lack effectiveness in explaining social reality. While a pluralist theory analysis does show it to be impossible to make hegemony fully accountable for the amendments, it is probably also not possible to discard it as a factor -however minor- at least during the period of PRI dominance.

This analysis has already proven that hegemony can be considered a minor factor, at most, in constitutional amendments and cannot be held solely accountable for the recent accelerated rate. What other factors could explain the amendments?

\section{A political conception of the constitution}

During the almost 100 years of the 1917 Constitution, its text has served as a canvas in which political programs are established with the paintbrush of congressional and presidential power.

Professor Valadés has described this phenomenon very clearly:

"Changes in the substance and form of the Constitution have occurred. However, they respond to the different phases of a country which has tried to leave the testimony of what in each moment constituted the most relevant of its political program in its constitutional amendments (...) There are various periods in our political development. The characteristics of each one of them are captured in the constitutional amendments." 34

In this sense, Professor Valadés's keen analysis implicitly argues that to a certain extent, reforms neglect the normative force of the constitution as they

$34 \quad$ VALADÉs, supra note 12 at 12. 
make a somewhat improper use of the text to make a declaration of specific political programs.

There are at least two different types of amendments which could be described as made under a political conception of the Constitution. There is what I call "political declaration amendments" and there is the constitutionalization of rights as programmatic principles.

In the first case, the constant declarations of the ideological nature of certain institutions can serve as an example. In 1934, the first amendment to Article 3 was made to establish that "education shall be socialist" as a declaration of Mexico's political stance at the time. Currently (and until the amendment of 2011), education shall:

"(...) tend to harmonically develop all faculties of human being and at the same time will promote love to the motherland, respect for human rights, and awareness of international solidarity in independence and justice."

As seen, the ideological components of the article on education are evident. The above-mentioned provisions would hardly translate into concrete obligations susceptible of constitutional control. They are rather perfectly explained under Valadés's theory as the consolidation of two different political programs under different historical circumstances. Multiple examples can be found in the Constitution.

In second place, we could argue that the continuous inclusion of rights, whose normative effectiveness cannot be guaranteed, is also a type of political declaration. We could call these rights "programmatic rights". One good example is Article 4, which contains the right to culture, the right to physical activity, the right to practice sports, the right to water, right to decent housing, the right to nutritious food, etc. The inclusion of these rights in the constitution would very much be in doubt had the political instances considered that there is an unconditional obligation of satisfying rights guaranteed by judicial bodies. In 2014, the CONEVAL [National Council for the Evaluation of Social Development Policy] reported that there are 11.4 million Mexicans living in extreme poverty, which represents $9.5 \%$ of the population. A good question is whether we can actually guarantee their right to decent housing, nutritious food and water? And whether the relevant political authorities view these rights as normative provisions? The answer is simple. The inclusion of such rights was regarded as a political and programmatic declaration, and not destined to become a normative force, at least for the time being.

\section{The regulatory nature of constitutional provisions}

Regulatory articles are both a cause and a consequence of constant amendments. The very specific nature of the rules established in constitutional articles is perplexing. Such level of detail comprises a concrete system that sets a variety of rules which cannot be amended by the corresponding provisions of relevant statutes. 
In this way, the Constitution becomes a secondary regulation, an ordinary law that contains the concrete rules governing individual cases instead of functioning as a framework of principles these rules should expound. Detailed dispositions in a constitution create constant problems as the amendment of such provisions necessarily requires an amendment to the Constitution itself.

A good example is the case of Article 41. Originally, Article 41 consisted of a single, 7-line paragraph. Those 7 lines contained 63 words. Currently, Article 41 has more than 70 paragraphs with nearly 5000 words. The level of detail in Article 41 (which currently regulates political parties and electoral administration) is truly surprising. It defines political parties and their creation, mathematical formulas for calculating public financing for political parties, percentages and differentiations of the financing depending on the type of election. It also sets rules for pre-campaigns, specifies the number of minutes (honestly, the number of minutes!) political parties are entitled to on television and in the media during campaigns, describes the complete organization of the National Electoral Institute, sets up a complex network outlining the powers of the National Electoral Institute and local electoral institutes, etc.

In conclusion, Article 41 is clearly set up as an Electoral Code. If, for instance, we wanted to assign propaganda time to political parties starting from 5 o'clock in the morning, we would need to amend the Constitution. The Constitution itself which disposes that such media time is distributed between 6.00 and 24.00. Therefore, simple amendments which in other countries would imply changing a regulation enacted by the executive power or at most a statutory provision imply here a change in the constitutional text.

The same case could be put forward with many provisions. Article 2 recognizes the rights of indigenous populations in Mexico. However, it also determinates the criteria for their recognition, grants them autonomy in the exercise of their right to self-determination and defines all the rights, one by one, which stem from this recognition. It establishes the obligation of the Federation and Federal Entities in these matters and even states that certain budget items related to indigenous rights should be included in the general budget.

Even the legislative faculties of the Federation suffer to a degree from this regulatory nature. Article 73 defines the legislative powers of the Federation, but in many cases it does so somewhat specifically. For example, the Federation has the power to establish taxes on "beer" (Section XXIX), a law on the organization of federal archives, a law on the distribution of powers of the Federation and Federal Entities in matters of electoral administration, legislation on sports, a law creating the Federal Administrative Court, etc.

Such way of defining powers has two main problems. In the first place, it questions the concept of a federalist system in which the Federation refuses to allow the consolidation of powers granted to the states in virtue of the closing clause (this will be discussed in the following section). In second place, it refuses to see the Constitution and federal powers as part of a constitutional system, which should be interpreted as a whole. In this sense, Congress and 
political actors feel that the scope of power of each must be expressly stated in the Constitution under specific terms. Otherwise, why does the Federal Congress have the power to enact a law that creates the Federal Administrative Court, but not the power to regulate administrative justice at a federal level? Why can the Federal Congress impose taxes on beer and not on alcoholic beverages? Why can the Federal Congress create a National Teacher Service / schools and cannot legislate on education?

It should not be forgotten that the Constitution itself provides a system of implicit powers. Section XXX of Article 73 clearly states that Congress has the power " $\mathrm{t}]$ o enact all laws that may be necessary to enforce the foregoing powers, and all others granted by this Constitution to the branches of the Union." Therefore in my view, it is beyond a doubt that many powers are implicitly contained in constitutional provisions and there is no need to elevate the specific details to competence clauses. A constitution can be interpreted by courts, political actors, branches of government and other relevant agents. Not everything has to be described word for word in the constitutional text.

\section{Centralization and Federalism}

Centralization can be deemed a true underlying cause of constitutional amendments. Of the 227 amendment decrees, 76 (or 33\%) have modified Article 73 of the Constitution, usually for the purpose of increasing federal legislative powers. As in the case of the other amendments, amendments to Article 73 have increased with political pluralism. In the first 82 years of the constitutional text, there was a rate of 0.53 amendments to Article 73 a year while after pluralism (2000), the rate goes up to a scandalous 2.12 amendments per year. Given the fact that Article 124 states that " $[\mathrm{t}]$ he powers not explicitly vested in federal officers by this Constitution shall be implicitly vested in the states and Mexico City," these continuous amendments are required to centralize power.

However, centralization is not only externalized through legislative powers. For example, an in-depth amendment of Article 41 was required to centralize electoral administration. A similar case can be put forward regarding the organizational of states. The Constitution has been progressively amended to impose specific organizational rules on the states, rules that basically define all their local constitutional elements. Consider the case of Articles 115 and 116, which altogether summed up to 8 paragraphs in the original 1917 Constitution and now have a total of 111 paragraphs. Even though the abovementioned articles should presumably provide a general framework of Federal Entities, the truth is that the free scope of the states is much diminished. Article 115 organizes municipalities and establishes their relationship with states, branches and powers. Article 116 regulates the internal organization of states, the organization of the three branches of local government, some 
constitutional autonomous organs to be created, auditing provisions, electoral administration, the regulation of local political parties, the administrative responsibility of the local judiciary, etc. These two articles combined have undergone 28 constitutional amendments. Arguably, most of these amendments reduce state powers regarding the self-determination of their constitutional organization by imposing certain conditions on them.

\section{Is Article 135 an "easy procedure"?}

Evidently and despite the abovementioned causes, an amendment procedure that has allowed more than 650 changes to the text through 227 amendment decrees raises doubts. I do not think the procedure is extremely flexible. However, given that potential amendments to the procedure have been proposed, I have analyzed some of the potential normative changes that could solidify the procedure established in Article 135 elsewhere. ${ }^{35}$

In the first place, the 2/3 majority mentioned above "the attending" deputies or senators greatly diminishes the difficulties in pushing through an amendment. The Chamber of Deputies is composed of 500 representatives while 128 members form the Senate. Article 63 establishes that " " $[\mathrm{n}]$ either the Chamber of Deputies nor the Chamber of Senators shall be allowed to open their sessions or perform their duties without the presence of at least half plus one of their respective members." This actually means that the Chamber of Deputies can vote on a constitutional amendment with only 251 members while the Senate requires 65. This means that 167.33 Deputies and 43.33 Senators can approve a constitutional amendment under certain conditions. The absence of any deputies and senators at their respective sessions should not alter the required quorum. If there is no interest in attending the respective session, it should be interpreted as a lack of interest in amending the Constitution.

Secondly, same considerations could apply to the required majority for Federal Entities. The current simple majority could be increased to match the one required, for example, in the United States (3/4).

Finally, under certain conditions other possible mechanisms would be to introduce a referendum for the approval of such amendments or to establish a minimum deliberation period from 3 to 6 months (as in Italy) to avoid fasttrack amendments.

35 See RiverA, supra note 22 at 192, 193.

36 On the debates regarding the calculation of a quorum, see Diego Valadés \& José María Serna, El cálculo del quorum en la Cámara de Diputados: una interpretación del artículo 63 constitucional, 108 Boletín Mexicano de Derecho Comparado 1038, 1052 (2003). 
Esta revista forma parte del acervo de la Biblioteca Jurídica Virtual del Instituto de Investigaciones Jurídicas de la UNAM

\section{Conclusions}

This article has shown that there is an impressive rate of constitutional amendments in Mexico. Hesse's remark is still valid today. Constant amendments under the pretext of seemingly ineluctable political needs endanger the normative force of the Constitution. ${ }^{37}$

As Bryce suggested:

"(...) the stability of any Constitution depends not so much on its form as on the social and economic forces that stand behind and support it; and if the form of the Constitution corresponds to the balance of those forces, their support maintain unchanged." 38

In the Mexican case, perhaps this instability can account not only for the present constant constitutional amendments, but also for historical constitutional changes in the Constitution of Cadiz, the Constitution of Apatzingan, the 1824 Federal Constitution, the 1836 Centralist Constitution, the 1857 Constitution and the 1917 Constitution. Mexican constitutional history is riddled with different constitutions with limited force.

Is it not possible that these dynamics has been passed on in the constitutional amendment rate of the 1917 Constitution? Can such rate be explained as part of the elasticity offered by flexible constitutions under the pretext of revolutions, civil war or, in the Mexican case, constant major political changes?

After the Mexican Revolution, the 1917 Constitution offered a social framework that institutionalized political demands. Constant amendments served as proof of a lack of the establishment of a strong system and the attention given to different demands in the form of political declarations in the constitution.

It has been argued in this article that there is no single cause for the constant amendments made to the Mexican Constitution. The amendments obey a complex structural framework, which includes partially the hegemony of a political party, a political conception of the Constitution, the regulatory nature of its provisions, an ongoing centralization process and perhaps too an amendment procedure that is unable to contain particular political dynamics.

The constant amendments have considerably damaged our constitutional system by preventing the consolidation of political institutions and producing an incoherent and overwhelmingly detailed regulatory text. However, in this specific case, normative solutions are unable to give a definitive answer to the problem. Either changing the amendment procedure (a normative padlock) or restructuring the Constitution (addressing the negative effects of the amendments) cannot be done by disregarding the underlying causes for the amendments. Overlooking the causes would result in the continuance of this Perpetuum Mobile Constitutio.

Received: April 13, 2016.

Accepted: Fuly 15, 2016.

37 Konrad Hesse, Die normative Kraft der Verfassung, 15 (C.B Mohr 1959).

38

BRYCE, supra note 1 at 20. 